JAMP: Jurnal Adminitrasi dan Manajemen Pendidikan

Volume 4 Nomor 4 Desember 2021, Hal : 338 - 349

Tersedia Online di http://journal2.um.ac.id/index.php/jamp/

ISSN 2615-8574 (online)

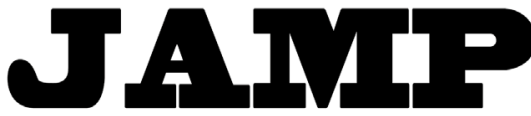

JURNAL ADMINISTRASI DAN MANAJEMEN PENDIDIKAN

\title{
THE EFFECT OF COMPETENCY, WORK MOTIVATION, WORK DISCIPLINE AND ORGANIZATIONAL COMMITMENTS ON TEACHER PERFORMANCE
}

\author{
Fajar Supanto $^{1}$, Yosefna Almesdirta Kara ${ }^{2}$, Muhammad Rizki Firdaus ${ }^{3}$ \\ ${ }^{1}$ Lecturer Faculty of Economics and Business, fajar.supanto@unmer.ac.id \\ ${ }^{2}$ Student in the Master of Management, yosefinakara@gmail.com \\ ${ }^{3}$ Lecturer Department of Business Administration, rizki.firdaus@unmer.ac.id \\ University of Merdeka Malang, Indonesia \\ Email: fajar.supanto@unmer.ac.id HP.081235188181
}

\begin{abstract}
This study aimed to describe the variables of competence, work motivation, work discipline, organizational commitment and teacher performance. In addition, analyzed the effect of competency variables, work motivation, work discipline, organizational commitment simultaneously affects teacher performance. The population were 100 respondents from Bina Sari Maumere Catholic Foundation teachers and the sample taken were 80 respondents. Furthermore, analysis of linear were used as a technique of analysis. The results showed that competency, work motivation, work discipline and organizational commitment simultaneously affected teacher performance. Similarly, those variables partially influenced teacher performance and Competence had a dominant effect on teacher performance at the Bina Sari Maumere Catholic Foundation as conclusion competence has a dominant effect on teacher performance.
\end{abstract}

Keywords: Competency; Work Motivation; Work Discipline; Organizational Commitment and Teacher Performance

teachers as one component of education that have an important role in improving the quality of education. Teachers are defined as professional educators with the main task of educating, teaching, guiding, directing, training, assessing, and evaluating students in early childhood through formal education, basic education, and secondary education (No.14, 2005 Law on Teachers and Lecturers). The low quality of teachers is caused by differences in the quality of performance, competencies, and abilities possessed by teachers which will affect the performance of teachers in improving the quality of education (Madjid 2016: 2). Therefore, teacher performance needs to be improved so that it can improve the quality of education.

Teacher performance is the behavior produced by a teacher in carrying out their duties as educators and instructors when teaching in front of the class according to certain criteria (Susanto, 2018: 70). To be able to measure and know the performance of a teacher, it is necessary to examine further the basic skills of teachers which are competence, work motivation, work discipline, and organizational commitment.

Competency mastery is the foundation for creating competent teacher performance. Thus, competence is defined as a set of knowledge, skills and behaviors that must be possessed, mastered and actualized by the teacher in carrying out professional tasks (Law Regulation No. 14 of 2005). In addition, competence is also defined as the ability of an individual to do various tasks in a job (Robbins in Ahmadi 2018: 17). 
In addition, other than competence, work motivation, and work discipline factors that can improve teacher performance, there are also other factors that affect teacher performance, organizational commitment. Commitment to the organization is a condition where an employee sided with an organization and its goals, and intends to maintain membership in the organization (Robbins and Judge, 2009: 20).

The Bina Sari Maumere Catholic Foundation is a private Catholic foundation that is social and active in the field of education. This educational institution does not have a few problems related to teacher performance. It is hoped that good teacher performance can be achieved through increasing teacher competency, work motivation, work discipline and organizational commitment. However, based on interviews and observations researchers found that the performance of teachers at the Bina Sari Maumere Catholic Foundation was less than optimal. This is due to not being fully supported by teacher competence, work motivation, work discipline and organizational commitment. Therefore, this educational institution needs to maintain its existence in the community so that it can face the challenges and competition of education in this digital era. The novelty of this research is that it wants to optimize teacher performance by examining the extent to which factors of competence, work motivation, work discipline and organizational commitment are able to leverage teacher performance.

This study consists of three hypotheses which based on the theoretical research and conceptual framework that has been studied. In addition, relevant previous research is one of the references for the author in conducting research so that it can enrich the author's insight in reviewing the research conducted. First hypotheses were Competence, Work Motivation, Work Discipline, Organizational Commitment simultaneously have a significant effect on Teacher Performance at the Bina Sari Maumere Foundationand. Simillary study conducted by Muhammad Arifin (2015). Second hypothesis explained that competence, work motivation, work discipline, organizational commitment partially has a significant effect on teacher performance at the Bina Sari Maumere Foundation, we found same study has conducted by Yenny (2019) and Setyawan (2016). Finally, third hypothesis described that competency has a dominant effect on teacher performance at the Bina Sari Maumere Foundation. There were two relevant studies found to support it such as (Hadiati, 2018) and Ningsih (2015)

The purpose of this study are: 1) Describe the variables of competence, work motivation, work discipline, organizational commitment and teacher performance; 2) Analyzing the effect of competency variables, work motivation, work discipline, organizational commitment simultaneously affect teacher performance; 3) Analyzing the effect of competency variables, work motivation, work discipline, organizational commitment partially influences teacher performance; 4) Knowing and analyzing among the variables of competence, work motivation, work discipline, organizational commitment, which have a dominant influence on the performance of the Bina Sari Maumere Catholic Foundation teachers.

\section{METHODS}

Based on the purpose of this study, the design of this study is an explanatory research with a quantitative approach, meaning that the researcher seeks to describe the causal relationship that occurs between the research variables and test the hypotheses that have been formulated (Singarimbun, 2005: 3). Explanatory research seeks to describe the relationship of hypotheses, explain competence, motivation work, work discipline, and organizational commitment. The picture will be found the relationship of each variable. The population in this study were all 100 Bina Sari Maumere Catholic Foundation teachers, while the sample consisted of 80 people in the form of questionnaires. The sampling technique uses the Proportional Random Sampling method. The data collection method uses a questionnaire that has been tested for validity and reliability.

Data analysis in this study uses descriptive analysis and multiple linear analysis. The equation model can be formulated as follows; $Y=\alpha+b_{1} X_{1}+b_{2} X_{2}+b_{3} X_{3}+b_{4} X_{4}+e$. Note: $Y=$ Teacher Performance, $\mathrm{X}_{1}=$ Competence, $\mathrm{X}_{2}=$ Work Motivation, $\mathrm{X}_{3}=$ Discipline, Work, $\mathrm{X} 4$ = Organizational Commitment, a $=$ Constant Value, $\mathrm{b}=$ Regression Coefficient, $\mathrm{e}=$ Residual Error. 


\section{Results}

\section{Respondents Description}

The number of respondents in this study were 80 teachers of the Bina Sari Maumere Catholic Foundation with different characteristics. Therefore, grouping with certain characteristics is needed. The following is descriptive data of respondents based on their characteristics.

Table 1. Respondents Characteristic

\begin{tabular}{lll}
\hline & Frequency & Percentage (\%) \\
\hline The identity of respondents & \\
Man & 32 & $40 \%$ \\
Women & 48 & $60 \%$ \\
Total & 80 & $100 \%$ \\
Age & & \\
$21-30$ & 5 & $7 \%$ \\
$31-40$ & 34 & $42 \%$ \\
$41-50$ & 21 & $26 \%$ \\
$51-60$ & 20 & $25 \%$ \\
Total & 80 & $100 \%$ \\
Years of service & & \\
$1-11$ & 28 & $35 \%$ \\
$12-21$ & 39 & $49 \%$ \\
$22-31$ & 7 & $9 \%$ \\
$32-41$ & 6 & $7 \%$ \\
Total & 80 & $100 \%$ \\
\hline
\end{tabular}

Sources : Data processed (2020)

\section{Validity and Reliability Test results}

Based on the results of the validity test of all items statement of each variable obtained a probability value smaller than $\alpha=0.05$. These results indicate that statement items of the variables of competence, work motivation, work discipline, organizational commitment and teacher performance in the questionnaire are valid because they have the ability to measure what should be measured. Based on the results of the reliability test showed that the variables of competence, work motivation, work discipline, and organizational commitment have a reliability coefficient of 0.60 . Thus, the instrument is feasible to be used in this study.

\section{Research Variables Desciption}

\section{Competency $\left(\mathrm{X}_{1}\right)$}

Table 2. Frequency Distribution of Competency $\left(\mathbf{X}_{1}\right)$

\begin{tabular}{llllllllllll}
\hline \multirow{2}{*}{ Item } & \multicolumn{2}{c}{ STS } & \multicolumn{2}{c}{ TS } & \multicolumn{2}{c}{ N } & \multicolumn{3}{c}{ S } & \multicolumn{3}{c}{ SS } & \multirow{2}{*}{ Mean } \\
& F & \% & F & \% & F & \% & F & \% & F & \% & \\
\hline X 1.1 & 0 & 0 & 0 & 0 & 9 & 11,2 & 56 & 70 & 15 & 18,8 & 4,07 \\
X 1.2 & 0 & 0 & 1 & 1,2 & 5 & 6,2 & 34 & 42,5 & 40 & 50 & 4,37 \\
X 1.3 & 0 & 0 & 0 & 0 & 7 & 8,8 & 44 & 55 & 29 & 36,2 & 4,27 \\
X 1.4 & 0 & 0 & 0 & 0 & 7 & 8,8 & 42 & 52,6 & 31 & 38,6 & 4,30 \\
X 1.5 & 0 & 0 & 0 & 0 & 5 & 6,2 & 49 & 61.2 & 26 & 32,6 & 4,26 \\
X 1.6 & 0 & 0 & 1 & 1,2 & 13 & 16,2 & 52 & 65 & 14 & 17,6 & 4,13 \\
X1.7 & 0 & 0 & 0 & 0 & 9 & 11,2 & 51 & 63,8 & 20 & 25 & 3,97
\end{tabular}




\begin{tabular}{|c|c|c|c|c|c|c|c|c|c|c|c|}
\hline \multirow{2}{*}{ Item } & \multicolumn{2}{|c|}{ STS } & \multicolumn{2}{|c|}{ TS } & \multicolumn{2}{|c|}{$\mathbf{N}$} & \multicolumn{2}{|c|}{$\mathbf{S}$} & \multicolumn{2}{|c|}{ SS } & \multirow{2}{*}{ Mean } \\
\hline & F & $\%$ & $\mathbf{F}$ & $\%$ & $\mathbf{F}$ & $\%$ & $\mathbf{F}$ & $\%$ & $\mathbf{F}$ & $\%$ & \\
\hline $\mathrm{X} 1.8$ & 0 & 0 & 4 & 5 & 3 & 3,8 & 37 & 46,2 & 36 & 45 & 4,03 \\
\hline X1.9 & 0 & 0 & 1 & 1,2 & 7 & 8,8 & 46 & 57,5 & 26 & 32,6 & 4,21 \\
\hline X1.10 & 0 & 0 & 2 & 2,5 & 11 & 13,7 & 48 & 60 & 19 & 23,8 & 4,05 \\
\hline X1.11 & 0 & 0 & 2 & 2,5 & 11 & 13,7 & 44 & 55 & 23 & 28,8 & 4,10 \\
\hline $\mathrm{X} 1.12$ & 0 & 0 & 1 & 1,2 & 9 & 11.2 & 45 & 56,3 & 25 & 31,3 & 4,17 \\
\hline $\mathrm{X} 1.13$ & 0 & 0 & 1 & 1,2 & 7 & 8,8 & 48 & 60 & 24 & 30 & 4,19 \\
\hline Mean & & & & & & & & & & & 4,18 \\
\hline
\end{tabular}

Sources : Data processed (2020)

From the respondent's answer Competencies $\left(X_{1}\right)$ items $X_{1.1}$ to $\left(X_{1.13}\right)$ state the respondent agrees to all items $X_{1}$ of the competency variable. The highest average score is 4.37 items $X_{1.2}$ (making learning design) and the lowest score is 3.97 items $\mathrm{X}_{1.7}$ (authoritative personality). The overall average has a value of 4.18 , meaning that the respondent agrees with the Competency $\left(\mathrm{X}_{1}\right)$ variable.

Work Motivation $\left(\mathbf{X}_{2}\right)$

Table 3. Frequency Distribution of Work Motivation $\left(\mathbf{X}_{2}\right)$

\begin{tabular}{lccccccccccc}
\hline \multirow{2}{*}{ Item } & \multicolumn{2}{c}{ STS } & \multicolumn{2}{c}{ TS } & \multicolumn{3}{c}{$\mathbf{N}$} & \multicolumn{3}{c}{ S } & \multicolumn{2}{l}{ SS } & \multirow{2}{*}{ Mean } \\
& $\mathbf{F}$ & $\mathbf{\%}$ & $\mathbf{F}$ & $\mathbf{\%}$ & $\mathbf{F}$ & $\mathbf{\%}$ & $\mathbf{F}$ & $\mathbf{\%}$ & $\mathbf{F}$ & $\mathbf{\%}$ & \\
\hline X 1.1 & 0 & 0 & 0 & 0 & 9 & 11,2 & 56 & 70 & 15 & 18,8 & 4,07 \\
X 1.2 & 0 & 0 & 1 & 1,2 & 5 & 6,2 & 34 & 42,5 & 40 & 50 & 4,37 \\
X 1.3 & 0 & 0 & 0 & 0 & 7 & 8,8 & 44 & 55 & 29 & 36,2 & 4,27 \\
X 1.4 & 0 & 0 & 0 & 0 & 7 & 8,8 & 42 & 52,6 & 31 & 38,6 & 4,30 \\
X 1.5 & 0 & 0 & 0 & 0 & 5 & 6,2 & 49 & 61.2 & 26 & 32,6 & 4,26 \\
Mean & & & & & & & & & & & 4,18 \\
\hline
\end{tabular}

The above table shows that from the answers to Work Motivation $\left(\mathrm{X}_{2}\right)$ for $\mathrm{X}_{2.1}$ to $\mathrm{X}_{2.5}$ state the respondent agrees to all items $X_{2}$ variable Work Motivation. The highest average value is 4.10 in the item statement item $\mathrm{X}_{2.2}$ (physiological needs) and the lowest average value is 4.01 in $\mathrm{X}_{2.3}$ (social needs). The overall average score of 4.04 means that the respondent agrees with the Work Motivation variable $\left(\mathrm{X}_{2}\right)$.

\section{Work Discipline $\left(\mathrm{X}_{3}\right)$}

Table 4. Frequency Distribution of Work Discipline $\left(\mathbf{X}_{3}\right)$

\begin{tabular}{cccccccccccc}
\hline \multirow{2}{*}{ Item } & \multicolumn{2}{c}{ STS } & \multicolumn{2}{c}{ TS } & \multicolumn{2}{c}{ N } & \multicolumn{2}{c}{ S } & \multicolumn{2}{c}{ SS } & \multirow{2}{*}{ Mean } \\
& F & \% & F & \% & F & \% & F & \% & F & \% & \\
\hline X 3.1 & 0 & 0 & 4 & 5 & 7 & 8,8 & 52 & 65 & 17 & 21,2 & 4,14 \\
X 3.2 & 0 & 0 & 4 & 5 & 9 & 11,2 & 51 & 63,8 & 16 & 20 & 4,10 \\
X 3.3 & 0 & 0 & 4 & 5 & 7 & 8,8 & 50 & 62,4 & 19 & 23,8 & 4,27 \\
Mean & & & & & & & & & & & 4,17 \\
\hline
\end{tabular}

Sources : Data processed (2020)

In the table above shows that from the answers to work discipline $\left(X_{3}\right)$ for $X_{3.1}$ to $X_{3.3}$ states the respondent agrees to all items $X_{3}$ variable work discipline. The highest average value is 4.27 for item $\mathrm{X}_{3.3}$ statement (compliant with superiors' regulations) and the lowest average value is 4.10 for statement items compliant with work procedures. The overall average has a value of 4,17 meaning that the respondent agrees with the Work Discipline variable (X3). 


\section{Organizational Commitment $\left(\mathbf{X}_{4}\right)$}

Table 5. Frequency Distribution of Organizational Commitment $\left(\mathrm{X}_{4}\right)$

\begin{tabular}{cccccccccccc}
\hline \multirow{2}{*}{ Item } & \multicolumn{2}{c}{ STS } & \multicolumn{2}{c}{ TS } & \multicolumn{2}{c}{ N } & \multicolumn{2}{c}{ S } & \multicolumn{2}{c}{ SS } & \multirow{2}{*}{ Mean } \\
& F & $\mathbf{\%}$ & F & $\mathbf{\%}$ & F & \% & F & \% & F & \% & \\
\hline X 4.1 & 0 & 0 & 2 & 2,5 & 7 & 8,8 & 46 & 57,5 & 25 & 31,2 & 4,01 \\
X 4.2 & 0 & 0 & 2 & 2,5 & 4 & 5 & 50 & 62,5 & 24 & 30 & 4,10 \\
X 4.3 & 0 & 0 & 3 & 3,7 & 7 & 8,8 & 50 & 62,5 & 20 & 25 & 4,00 \\
Mean & & & & & & & & & & & 4,03 \\
\hline
\end{tabular}

Sources : Data processed (2020)

In the table above shows that from the answer Organizational Commitment $\left(\mathrm{X}_{4}\right)$ for $\mathrm{X}_{1.1}$ to $\mathrm{X}_{4.3}$ states the respondent agrees to all items $\mathrm{X}_{4}$ variable Organizational Commitment. The highest average value is 4.10 for statement item $X_{4.2}$ (normative commitment) and the lowest average value is 4.00 for statement item $\mathrm{X}_{4.3}$ (ongoing commitment). Overall average value of 4,03 means that the respondent agreed to the variable Organizational Commitment $\left(\mathrm{X}_{4}\right)$.

Teacher Performance (Y)

Table 6. Frequency Distribution of Teacher Performance (Y)

\begin{tabular}{cccccccccccc}
\hline \multirow{2}{*}{ Item } & \multicolumn{2}{c}{ STS } & \multicolumn{2}{c}{ TS } & \multicolumn{3}{c}{$\mathbf{N}$} & \multicolumn{3}{c}{ S } & \multicolumn{2}{c}{ SS } & \multirow{2}{*}{ Mean } \\
& $\mathbf{F}$ & $\mathbf{\%}$ & $\mathbf{F}$ & $\mathbf{\%}$ & $\mathbf{F}$ & $\mathbf{\%}$ & $\mathbf{F}$ & $\mathbf{\%}$ & $\mathbf{F}$ & $\mathbf{\%}$ & \\
\hline Y1.1 & 0 & 0 & 1 & 1,2 & 4 & 5 & 48 & 60 & 27 & 33,8 & 4,28 \\
Y1.2 & 0 & 0 & 1 & 1,2 & 8 & 10 & 40 & 50 & 31 & 38,8 & 4,26 \\
Y1.3 & 0 & 0 & 2 & 2,5 & 7 & 8,8 & 41 & 51,2 & 30 & 37,5 & 4,23 \\
Y1.4 & 0 & 0 & 3 & 3,7 & 5 & 6,2 & 54 & 67,5 & 18 & 22,6 & 4,09 \\
Y1.5 & 0 & 0 & 3 & 3,7 & 5 & 6,2 & 47 & 58,8 & 25 & 31,3 & 4,18 \\
Mean & & & & & & & & & & & 4,20 \\
\hline
\end{tabular}

Sources : Data processed (2020)

Table above shows that from the answers Teacher Performance $(Y)$ for $Y_{1.1}$ to $Y_{1.5}$ states the respondent agrees to all items $\mathrm{Y}$ Teacher Performance variables. The highest average value is 4.28 for

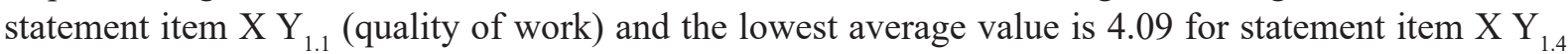
(ability to work). Overall average has a value of 4, 20 means that respondents agreed to the Teacher Performance variable (Y).

\section{Multiple Regression Analysis}

Table 7. Results of Multiple Regression Analysis

\begin{tabular}{|c|c|c|c|}
\hline Variable & Regression Coeffcient & $\mathbf{t}$ & Sig. \\
\hline Competence & 0,436 & 4,852 & 0,000 \\
\hline Work Motivation & 0,016 & 1,237 & 0,171 \\
\hline Work Discipline & 0,346 & 2,582 & 0,000 \\
\hline Commitment Organizational & 0,045 & 0,427 & 0,524 \\
\hline Constant & & \multicolumn{2}{|c|}{1,427} \\
\hline R square & & \multicolumn{2}{|c|}{0,832} \\
\hline Adjusted R square & & \multicolumn{2}{|c|}{0,676} \\
\hline F count & & \multicolumn{2}{|c|}{42,299} \\
\hline Sig. F & & \multicolumn{2}{|c|}{0,000} \\
\hline $\mathrm{N}$ & & \multicolumn{2}{|c|}{80} \\
\hline $\mathrm{F}$ table $=$ & & \multicolumn{2}{|c|}{3,12} \\
\hline $\mathrm{t}$ table $=$ & & \multicolumn{2}{|c|}{2,000} \\
\hline The dependent Variable $=$ Teache & & & \\
\hline
\end{tabular}


The value of multiple linear regression constants is 1,427 , with the regression coefficient value of competence variable 0.436 , the regression coefficient value of work motivation 0.016 , the value of the regression coefficient of work discipline 0.346 and the regression coefficient value of 0.045 . So by referring to the formula of multiple linear regression equations. $Y=a+b_{1} \cdot X_{1}+b_{2} \cdot X_{2}+b_{3} \cdot X_{3}+b_{4} \cdot X_{4}+$ ei, multiple linear equations can be formed as follows: $Y=1,429+0,436 \cdot X_{1}+0,016 \cdot X_{2}+0,346 \cdot X_{3}+$ 0,045. $\mathrm{X}_{4}+$ ei . Where: $\mathrm{Y}=$ Teacher Performance, $\mathrm{X} 1=$ Competence, $\mathrm{X} 2=$ Work Motivation, $\mathrm{X} 3=$ Work Discipline, $\mathrm{X} 4$ = Organizational Commitment, ei = Residual Error

The significance of the multiple linear regression equation above has implications: 1,427 connote when variables competency, work motivation, work discipline, and organizational commitment. The regression coefficient $\mathrm{X}_{1}$ (competence) 0.436 and having a positive sign implies a directional effect, if an increase in the competency variable will have a tendency followed by an increase in teacher performance. The regression coefficient $\mathrm{X}_{2}$ (work motivation) 0.016 and having a positive sign implies a direct effect, if an increase in the variable of Work Motivation will have a tendency followed by an increase in teacher performance. The regression coefficient $\mathrm{X}_{3}$ (work discipline) 0.346 and having a positive sign implies that there is a direct effect, if an increase in work discipline variables will have a tendency followed by an increase in teacher performance. The regression coefficient $\mathrm{X}_{4}$ (Organizational Commitment) 0.045 and having a positive sign implies a direct effect, if there is an increase in the variable of work motivation it will have a tendency followed by an increase in teacher performance. The coefficient of determination is 0.676 . It has implications that the variables of competence, work motivation, work discipline, organizational commitment affect the performance of the Bina Sari Maumere Foundation teacher by $67.6 \%$.

\section{Test Multicollinearity}

To detect the presence or absence of multicollinearity by looking at the Tolerence and VIF values. If tolerance is more than 0.1 and VIF is less than 10 then there is no multicollinearity.

Table 8. Colinearity the Analysis Multicolinearitas

\begin{tabular}{lll}
\hline \multicolumn{1}{c}{ Variable } & \multicolumn{1}{c}{ Tolerence } & VIF \\
\hline X1 Competence & 0,975 & 1,025 \\
X2 Work Motivation & 0,469 & 2,133 \\
X3 Work Discipline & 0,629 & 1,589 \\
X4 Organizational Commitment & 0,506 & 1,977 \\
\hline
\end{tabular}

Sources : Data processed (2020)

The table shows that there are no problems arising from the multicollinearity independent variable, VIF value is less than 10 then this research model has no multicollinearity problem.

\section{Test Heteroscedasticity}

The following table is the result of heteroscedasticity test of competency variables, work motivation, work discipline, organizational commitment to teacher performance.

Table 9. Heteroscedasticity Analysis Data

\begin{tabular}{ll}
\hline \multicolumn{1}{c}{ Variable } & Value Sig \\
\hline Competence & 0,888 \\
Work Motivation & 0,982 \\
Work Discipline & 0,184 \\
Organizational Commitment & 0,120 \\
\hline
\end{tabular}

Sources : Data processed (2020)

It is clear that heteroscedaticity problems do not arise from the independent variables because the sig value of each variable is $>0.05$. 


\section{Test Autocorrelation}

Priyatno (2013: 62) to detect the presence or absence of autocorrelation by the Durbin-Watson test. The following Durbin - Watson (DW) statistics can produce dU and dL values.

Table 10. Testing Autocorrelation

\begin{tabular}{lrllll}
\hline Model & R & R Square & Adjusted R Square & Std. Error of the Estimate & Durbin-Watson \\
\hline 1 & $.832 \mathrm{a}$ & .693 & .676 & 2.55368 & 2.141 \\
\hline
\end{tabular}

Sources : Data processed (2020)

From the output above the DW value obtained from the regression model is 2.141 . While from the DW table with a significance of $5 \%$ and the amount of data $\mathrm{n}=80$ and $\mathrm{k}=5$, the value of $\mathrm{dL}=1.5070$ and $\mathrm{dU}=1.7716$ due to the DW value (DW 2,141) is located between dU $(1,7716)$ and 4-dU $(2,228)$ then Ho is accepted, which means no autocorrelation.

\section{Normality Test}

Testing of Normal Probability with decision-making criteria as follows:

Table 11. Result data using SPSS;

\begin{tabular}{llllll}
\hline & $\mathrm{N}$ & Skewness & \multicolumn{3}{c}{ Kurtosis } \\
& Statistics & Statistics & Std. Error of Skewness & Statistics & Std. Error of Kurtosis \\
\hline Unstandardized Residual & 80 & $-0,445$ & 0,269 & $-0,683$ & 0,532 \\
Valid N & 80 & & & & \\
\hline
\end{tabular}

Sources : Data processed (2020)

From the table above it is clear that the Skewnees ratio $=-0.445 / 0.269==1.65$ while the Kurtosis ratio $=-0.673 / 0.532=-1,28$. Therefore it is concluded that the distribution of existing data is normal. Based on the table above the ratio of skewnees and kurtosis obtained -1.65 to -1.28 .
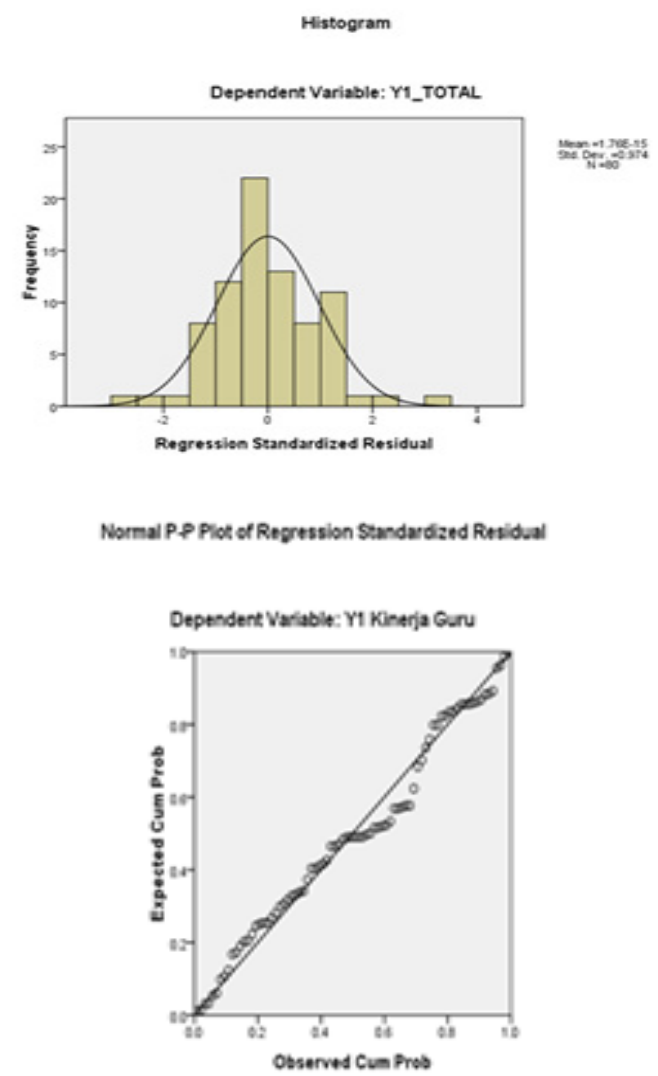


\section{First Hypothesis}

Table 12. Results F Test

\begin{tabular}{llllcc}
\hline \multicolumn{1}{c}{ Model } & Sum of Squares & df & Mean Square & F & Sig. \\
\hline Regression & 927.162 & 4 & 275.847 & 42.299 & $.000 \mathrm{a}$ \\
Residual & 489.098 & 75 & 6.521 & & \\
Total & 1595.488 & 79 & & & \\
\hline
\end{tabular}

Sources : Data processed (2020)

Processing data using SPSS results calculated $F=42,299$. Competency $\left(X_{1}\right)$, work motivation $\left(X_{2}\right)$, work discipline $\left(\mathrm{X}_{3}\right)$, and organizational commitment $\left(\mathrm{X}_{4}\right)$ simultaneous influence on $(\mathrm{Y})$. Therefore it can be concluded that the first hypothesis is statistically proven by $\alpha 5 \%$.

\section{Second Hypothesis}

Table 13. Partial Regression Coefficient Test

\begin{tabular}{lcccl}
\hline \multicolumn{1}{c}{ Variable } & $\mathbf{t}_{\text {count }}$ & $\mathbf{t}_{\text {table }}$ & sig & Information \\
\hline Competence & 4,852 & 2,000 & 0,000 & Significant \\
Work Motivation & 1,237 & 2,000 & 0,171 & Not Significant \\
Work Discipline & 2,582 & 2,000 & 0,000 & Significant \\
Organizational Commitment & 0,427 & 2,000 & 0,520 & Not Significant \\
\hline
\end{tabular}

Sources : Data processed (2020)

Based on the calculation of the sig value in table 13 which states that the Competency variable $\left(\mathrm{X}_{1}\right)$ and the Work Discipline variable $\left(\mathrm{X}_{3}\right)$ significantly influence the Teacher Performance variable $(\mathrm{Y})$, while the Work Motivation variable $\left(\mathrm{X}_{2}\right)$ and the Organizational Commitment variable $\left(\mathrm{X}_{4}\right)$ are declared to have no influence significant to the Teacher Performance variable (Y), thus partially having no effect it can be concluded that the second hypothesis is proven statistically with $\alpha 5 \%$.

\section{Third Hypothesis}

Table 14. Results of Dominant Variable Regression Coefficient Tests

\begin{tabular}{lcccccl}
\hline \multicolumn{1}{c}{ Variable } & $\mathbf{B}$ & t count & t table & sig & $\boldsymbol{\alpha}$ & \multicolumn{1}{c}{ information } \\
\hline Competence & 0,436 & 4,852 & 2,000 & 0,000 & 0,05 & Significant \\
Work Motivation & 0,016 & 1,237 & 2,000 & 0,171 & 0,05 & Not Significant \\
Work Discipline & 0,346 & 2,582 & 2,000 & 0,000 & 0,05 & Significant \\
Organizational Commitment & 0,045 & 0,427 & 2,000 & 0,520 & 0,05 & Not Significant \\
\hline
\end{tabular}

Sources : Data processed (2020)

From the calculation above, found the coefficient of Competency variables $\left(\mathrm{X}_{1}\right) 4,852$, work motivation $\left(X_{2}\right)$ 1,237, work discipline $\left(X_{3}\right) 2,582$, and organizational commitment $\left(X_{4}\right)$ 0,427. Thus, the variable of work motivation and organizational commitment does not significantly influence teacher performance and the variable of work discipline is not a variable that has a dominant effect on teacher performance. From the results of these calculations there is the greatest coefficient is Competence $\left(\mathrm{X}_{1}\right)$ 4.852 which means that it has a significant effect on teacher performance (Y). Thus, the third hypothesis is proven statistically with $\alpha 5 \%$.

\section{DISCUSSION}

\section{Effect of Competence, Work Motivation, Work Discipline, Organizational Commitment Performance Simultaneous Teacher}

The results of the analysis showed that Competency, Work Motivation, Work Discipline, Organizational Commitment simultaneously affect the Performance of the Bina Sari Maumere Catholic 
Foundation with a significance value of $0.00<0.05$. According to Jamil (2012) competencies are divided into four parts, namely pedagogical competencies, social competencies, personality competence and professional competence. The conclusions obtained from this study support the results of research conducted by Yenny (2018) at the Imanuel Palu Education Foundation, Indonesia which say that competence, work discipline, work motivation, have a significant effect on teacher performance.

In addition to aspects of competence that can improve teacher performance, work motivation is also one of the factors that determine a person>s performance. «Teacher»s work motivation is defined as a process undertaken to move teachers so that their behavior can be directed to concrete efforts to achieve goals that are has been established (Uno; 2016,71). The teacher can perform well if the physiological needs, security, social needs, appreciation needs and self-actualization needs are met. Therefore, educational institutions need to pay attention to factors that support motivation. This is consistent with Ismail >s (2017) research which says that work motivation influences the performance of elementary school teachers in North Cimahi, Indonesia.

In addition to the two aspects above, the teacher also needs to realize the importance of work discipline. The better the discipline of work, the higher the teacherss performance. This research proves that discipline greatly influences teacher performance in carrying out their duties. This is in accordance with Turangan $>$ s research (2017) that Competence, Work Discipline and Professionalism influence Teacher Performance in SMA Negeri 1 Manado, Indonesia.

The organizational commitment aspect is also an aspect that has an influence on improving teacher performance. Teachers〉 commitment to agencies will encourage good performance (Gibson, 2009). With affective commitment, ongoing commitment and normative commitment, teacher performance will increase. Therefore, this educational institution needs to pay attention to these aspects. This is in accordance with research conducted by Ardinata (2017) on the Effect of Competence, Organizational Commitment, Professionalism on Teacher Performance (Study at Azhar Syifa Budi II School, Pekanbaru City, Indonesia.

The conclusions from the results obtained provide evidence that competence, work motivation, work discipline, organizational commitment together have a role for the creation of good performance. Teachers who are competent in learning planning, can create interactive communication in carrying out their duties. Based on the results of the coefficient of determination test, the effect given competence, work motivation, work discipline and organizational commitment to the performance of the Bina Sari Maumere Catholic Foundation by $67.6 \%$, the remaining $32.4 \%$, influenced by other variables namely organizational climate, Organizational culture, work ethic, and so on in this study are not used as the main focus.

\section{Effect of Competence Variables on Teacher Performance}

The results showed that competence had a significant effect on the performance of the Bina Sari Maumere Catholic Foundation teachers with a significance value of $0,000<0.05$. The quality of the education process is determined by the competencies of the teachers. This is caused by the teacher>s role as the spearhead in education. This result is supported by research conducted by Saragih (2016) which states that competence has a significant effect on teacher performance. In addition, it was also strengthened by the results of observations and interviews that the competency variable is an important aspect that must be present, lived and implemented by teachers at the Bina Sari Maumere Catholic Foundation. The teachers feel that their competencies are less effective so that it impacts on their performance as educators. Therefore, teachers realize that competence has a significant influence on teacher performance.

\section{Effect of Motivational Variables on Teacher Performance}

The results showed that motivation had no significant effect on teacher performance with a significance value of $0.171>0.05$. From the results of observations and descriptive analysis results, the indicators of allowances in accordance with workload and getting bonuses from work performance do not affect the performance of Bina Sari Maumere Foundation teachers. This is supported by research 
with results that show that leadership style and motivation have a negative and insignificant effect on teacher performance such as research conducted by Guritno (2012) at SMAN in Temanggung District, Indonesia. Broadly speaking, respondents feel physiological needs, the need for security, social needs, self-esteem needs and self-actualization needs feel fulfilled which means that internal motivation has been fulfilled so that there is or no work motivation, teacher performance remains good. Thus, based on data findings in the field that the motivation variable does not affect the performance of Bina Sari Maumere Catholic Foundation teachers.

\section{Effect of Work Discipline Variables (X3) on Teacher Performance (Y)}

The results showed that work discipline had a significant effect on teacher performance with a significance value of $0,000<0.05$. This is consistent with Turangan's research (2017) that Competency, Work Discipline and Professionalism affect Teacher Performance. This result is reinforced by observations and interviews that the work discipline of Yayasasan Bina Sari teachers needs to be improved. The teachers realize that in devoting themselves as educators, they lack discipline so this affects their performance. Thus, teachers realize that work discipline has a significant effect on teacher performance.

\section{Effect of Organizational Commitment Variable (X3) on Teacher Performance (Y)}

The results showed that organizational commitment affected teacher performance with a value of $0.524>0.05$. From observations and descriptive analysis results, indicators of normative commitment did not affect the performance of Bina Sari Maumere Catholic Foundation teachers. This is supported by research with results that show that compensation and organizational commitment have a negative and not significant effect on teacher performance such as research conducted by Handoyo (2012). Broadly speaking, respondents feel organizational commitment is something that is inherent in themselves and this has become a habit for them to carry out their duties at the Bina Sari Maumere Catholic Foundation. Thus, the variable organizational commitment does not significantly influence teacher performance.

\section{Competence Has a Dominant Effect on Teacher Performance}

The results of testing the third hypothesis states that teacher competence has a dominant effect on teacher performance. This can be proven by the linear regression coefficient multiple of 0.436 and a count of 4.852. Based on the results above it will be described how much influence the four competencies have on teacher performance. Pedagogic competence, must be possessed because it is related to the ability of teachers in managing the learning process and understanding the characteristics of students. The results of the study stated that most of the teachers as respondents expected to be able to make student learning design. In addition, teachers also expect to be able to create learning that educates students, evaluate learning outcomes and develop students to actualize the potential that exists in themselves. This is consistent with Sumartini's research (2017) in Girimulyo District, Kulon Progo Regency, Indonesia. The higher the teacher's pedagogical competence, the higher the teacher's performance towards educational institutions. Therefore, teachers with high pedagogical competence also have high performance in managing student learning.

Personality competence must be possessed because it is related to the attitudes and behavior of the teacher that reflects his personal personality. Teachers who have authoritative personality competencies have good performance that can be manifested in their attitudes and behavior towards students. The results of the study stated that most of the teachers as respondents expected to have a noble character by saying and being honest in all things and having a simple attitude. In addition, the teacher also expects to have a personality that is wise and authoritative. This is consistent with Agung >s research (2017). The higher the teacher s personal competency, the higher the teacherss performance towards educational institutions. Therefore, teachers with high personality competencies have high performance too.

Social competence must be possessed because it is related to the interaction between the teacher and various parties both students> co-workers, and parents of students. The results of the study stated that most of the teachers as respondents expected to be able to interact with students namely by providing motivation to learn to students, able to establish dialogue with students and be able to pay attention to 
good communication with students. In addition, teachers also expect to be able to interact with parents and colleagues. This is in accordance with Zenitass research (2017). The higher the teacher ss social competence, the higher the teacher $>$ s performance towards educational institutions. Therefore, teachers with high social competence also have high performance.

Professional competence must be possessed because it relates to the ability of teachers to master learning material widely and deeply so that it is able to transfer it to students. This ability is part of the performance in the mastery of scientific substance. The results of the study stated that most of the teachers as respondents expected to be able to master the scientific substance related to the field of study being taught ie being able to describe scientific authority and its limitations and to relieve teaching material with current conditions. In addition, the teacher also expects to master the structure and methods of science by conducting classroom action research, involving students in research and disseminating research results to the general public. This is consistent with Pamungkas research (2017) in Boyolangu District, Tulungagung Regency, Indonesia. The higher the teacherss professional competence, the higher the teacher>s performance towards educational institutions. Therefore, teachers with high professional competence also have high performance in managing student learning.

\section{Implications}

The results showed that the variables that had a significant effect on teacher performance were competency and work discipline variables. The quality of the education process is determined by the competencies of the teachers. This is caused by the teacher's role as the spearhead in education. The teachers at the Bina Sari Maumere Catholic Foundation feel that their competencies are less effective and thus have an impact on their performance as educators. Therefore, the competence of teachers at the Bina Sari Maumere Catholic Foundation needs to be maintained and enhanced again by providing opportunities for teachers to broaden their horizons by mastering IT-based learning. In addition to competence, work discipline is also a variable that has a significant effect on teacher performance. The Yayasasan Catholic teachers Bina Sari Maumere realized that in devoting herself as an educator, she lacked discipline so this affected her performance. Thus, work discipline needs to be maintained and improved by giving rewards to teachers who arrive on time and attendance and punishment for teachers who are not on time in teaching.

In addition to the two variables above, as for the variables that do not significantly influence teacher performance including work motivation and organizational commitment. The teachers at the Bina Sari Maumere Catholic Foundation feel that the physiological needs, the need for security, social needs, self-esteem needs and self-actualization needs have been fulfilled, meaning that there is or no internal work motivation the teacher's performance remains good. Likewise, organizational commitment. The teachers at the Bina Sari Maumere Catholic Foundation feel organizational commitment is something that is inherent in themselves and has become a habit for them to carry out their duties at the Bina Sari Maumere Foundation. For this reason, the Bina Sari Maumere Catholic Foundation needs to conduct an evaluation of the work motivation and organizational commitment of the teachers and also improve these two aspects so as to improve teacher performance.

\section{CONCLUSION}

Simultaneously competency, work motivation, work discipline, and organizational commitment affect the performance of Bina Sari Maumere Foundation teachers. The higher the competency, work motivation, work discipline, and organizational commitment, the teacher's performance will be higher. Futhermore, Motivational variables and organizational commitment variables have no significant effect on teacher performance. This is influenced by physiological needs, security, social needs, selfesteem needs and self-actualization needs of the teaching staff at the Bina Sari Maumere Foundation which have been fulfilled, which means that internal motivation has been fulfilled so that there is or no work motivation, teacher performance remains good. In addition, Bina Sari Maumere Foundation's educators have become accustomed to organizational commitment, so organizational commitment is not 
new to them. Thus, it was concluded that Competency (X1), Work Motivation (X2), Work Discipline (X3), Organizational Commitment (X4) partially had no effect on teacher performance (Y) of the Bina Sari Maumere Foundation. Finally, Competencies has a dominant effect on teacher performance. Good competence in carrying out their duties and functions as a teacher is needed in the world of education, especially in improving teacher performance. This shows that the main aspect that needs to be considered in improving teacher performance is the extent to which competencies contribute to teaching and learning activities.

\section{Recommendations}

Teacher competency needs to be maintained and enhanced again by providing opportunities for teachers to broaden their horizons by mastering IT-based learning. Work discipline needs to be maintained and improved by giving rewards to teachers who arrive on time and attendance and punishment for teachers who are not on time in teaching. Work motivation and organizational commitment should be evaluated and increased again, although the regression coefficients of the two variables are low and insignificant, but a positive value of the two variables can affect teacher performance. For further researchers it is recommended to examine other variables, for example organizational climate, organizational culture, work ethics and so on.

\section{REFERENCES}

Ardinata (2017). Pengaruh Kompetensi, Komitmen Organisasional, Profesionalisme terhadap Kinerja Guru (Studi Pada Sekolah Azhar Syifa Budi II Kota Pekanbaru), Jurnal Online Mahasiswa Fakultas Ekonomi Vo.4 No.1 Februari.

Gibson \& James (2009) Organisasi dan Manajemen: Perilaku, Struktur, dan Proses. Erlangga: Jakarta.

Hadiati, E. (2018). Pengaruh Disiplin Kerja Terhadap Kinerja Guru Mts Se- Kota Bandar Lampung. Al-Idarah: Jurnal Kependidikan Islam, 8(1), 50. https://doi.org/10.24042/alidarah.v8i1.3078

Muhammad Arifin, H. (2015). The influence of competence, motivation, and organisational culture to high school teacher job satisfaction and performance. International Education Studies, 8(1), 38-45. https://doi. org/10.5539/ies.v8n1p38

Ningsih, P. (2015). Pengaruh Komitmen, Kompetensi, Dan Lingkungan Kerja Terhadap Kinerja Guru Di Kecamatan Pasangkayu Kabupaten Mamuju Utara. Kataogis, 5(7), 181-190.

Setyawan, H. (2016). Pengaruh Kompetensi, Komitmen Organisasional Dan Profesionalisme Guru Terhadap Kinerja Guru (Studi Pada Sekolah Al Azhar Syifa Budi II Kota Pekanbaru). Pengaruh Etika Uang Terhadap Kecuranagan Pajak Dengan Religiusitas, Gender Dan Materialisme Sebagai Variabel Moderasi, 2(2), 20102012.

Yenny. (2019). Pengaruh Kompetensi, Motivasi dan Disiplin Kerja terhadap Kinerja Guru pada Yayasan Pendidikan Imanuel Palu. Jurnal Katalogis, 6(2), 98.

Ismail, Ismail, Taufik (2017). Kepemimpinan, Kompensasi, Motivasi Kerja, Dan Kinerja Guru SD Negeri, Jurnal Administrasi Pendidikan Vol.XXIV No.1 April.

Jamil, Suprihatiningrum, 2014, Strategi Pembelajaran,Yogyakarta: Insan Madani.

Madjid, Abdul, (2016). Pengembangan Kinerja Guru Melalui: Kompetensi, Komitmen dan Motivasi Kerja, Yogyakarta: PT. Samudra Biru.

Robbins \& Judge (2009). Perilaku Organisasi, Jakarta: Salemba.

Susanto \& Ahmad (2018). Manajemen Peningkatan Kinerja Guru, Depok: Prenada Media Group.

Turangan, Jeine K, 2017, Pengaruh Kompetensi, Disiplin Kerja, dan Profesionalisme Terhadap Kinerja Guru di SMA NEGERI 1 MANADO, Jurnal EMBA, Vol.5 No. 2, Juni.

Undang-Undang RI No. 14 Tahun 2005 Tentang Guru dan Dosen. Jakarta.

Uno, H. B,2012, Teori kinerja dan pengukurannya. Jakarta: Bumi Aksara.

Zenita, Ferni Irawani, 2017, Pengaruh Kompetensi Sosial Dan Disiplin Kerja Terhadap Kinerja Guru Di SMA Negeri 7 Muaro Jambi, Scientific Journals of Economic Education, Volume 1, Nomor 1, September. 